\title{
Liệu có thể tin Việt Nam sẽ là con hổ châu Á?
}

An Ngoc

\section{Tù̀ nền kinh tế đi lên từ chiến tranh, thuộc nhóm 20 nước nghèo nhất thế giới}

30/4/1975, Việt Nam mới hoàn toàn chấm dứt chiến tranh, thống nhất đất nước và đi lên xây dựng kinh tế với rất nhiều khó khăn. Viện trợ tiếp tục đóng vai trò quan trọng trong việc đảm bảo an ninh kinh tế tối thiểu, với khoản viện trợ đầu tiên vào năm 1978 do Liên Xô và các nước XHCN khác đóng góp khoảng 1,2 tỷ USD.

Trong nghiên cứu Kinh tế Việt Nam: Thăng trầm và đột phá của hai tác giả Phạm Minh Chính và Vương Quân Hoàng cũng đưa ra, thu nhập bình quân đầu người của Việt Nam ở giai đoạn này chỉ khoảng từ 125 đến 200 USD. So với thu nhập của các nước như Myanmar, Trung Quốc, Thái Lan năm 1982 lần lượt là 170 USD, 228 USD và 816 USD, thì Việt Nam chỉ tương đương Myanmar và xếp trong nhóm 20 nước nghèo nhất thế giới.

Cho đến trước khi Đổi mới vào năm 1986, kinh tế Việt Nam rơi vào khủng hoảng kéo dài. Có thời điểm, số lao động thất nghiệp chiếm tới 23,89\% trên tổng số lượng lao động; trong khi mức tiết kiệm cũng như hiệu quả đầu tư liên tục giảm; lạm phát phi mã đên lên tới gần $500 \%$ giữa những năm 1980...

Cán cân thương mại liên tục bị thâm hụt, kinh tế vẫn bị phụ thuộc vào viện trợ từ Liên Xô. Tính đến thời điểm trước Đổi mới, tổng số nợ của Việt Nam với 30 quốc gia và tổ chức quốc tế khác là 2,7 tỷ USD. Những áp lực nội tại của nền kinh tế đặt ra nhu cầu đổi mới toàn diện và sâu sắc mà Đảng đã xác định tại Đại hội lần thứ VI.

Với tư duy kinh tế thị trường ngày càng dứt khoát, rõ ràng, thể hiện trong nhiều chủ trương, công cuộc Đôi mới đã được khởi động từ năm 1986. Định hướng này đã mang lại thành quả và bước đột phá cho nền kinh tế, khi GDP duy trì tăng trưởng ổn định 8-9\% trong gần hết những năm 1990. Mặc dù có khủng hoảng tài chính 1997 nhưng Việt Nam bị tác động ít hơn so với các nước láng giềng như Thái Lan, Hàn Quốc hay Indonesia.

Hoạt động ngoại thương được đánh giá là có nhiều tích cực, khi cán cân xuất nhập khâuu bình quân giai đoạn 1986 đến 2005 là 20,7 tỷ USD, gấp 7 lần so với năm 1985. Tốc độ tăng trưởng qua các thời kỳ cũng rất cao, có giai đoạn lên tới trên 18\%, riêng xuất khâu luôn tăng trên mức $20 \%$.

Từ 40 DN trực tiếp xuất khẩu đã tăng lên 20.000 vào cuối năm 2005, với sự đóng góp quan trọng của FDI. Đây chính là kêt quả của việc thu hút FDI tăng lên nhanh chóng trong thời gian qua.

... Sự bứt phá của kinh tế đã tới hạn, cần cuộc cải cách lần hai? 
Trở lại Việt Nam sau 20 năm, Thủ tướng Anh ông David Cameron đã bày tỏ sự ấn tượng về sự phát triển mạnh mẽ của Việt Nam khi GDP đã tăng 350\%. Theo đánh giá của Liên Hợp quốc, những cải cách trong Đổi mới đã giúp Việt Nam đạt được kết quả tăng trưởng, kể từ năm 1990 tỷ lệ tăng bình quân ước đạt $7,5 \%$. Nhờ vậy, tỷ lệ phần trăm dân số dưới chuẩn nghèo đã giảm từ con số 58\% năm 1993 xuống dưới 10\%.

Ngân hàng Thế giới cũng đánh giá công cuộc Đổi mới kinh tế và chính trị đã đưa Việt Nam từ một trong những quốc gia nghèo nhất trên thế giới với thu nhập bình quân đầu người dưới 100 USD, thành quốc gia có thu nhập trung bình thấp chỉ trong vòng 25 năm với thu nhập bình quân đầu người lên tới 2.109 USD năm 2015.

Đáng chú ý là Việt Nam đã đạt được những thành tựu quan trọng trong hội nhập đang mở ra nhiều cơ hội. Hiện Việt Nam có quan hệ thương mại tự do với 55 quốc gia, trong đó có 15 nước nhóm G20. Điều này đã giúp Việt Nam có lợi thế thu hút tốt dòng vốn FDI đang chuyển dịch từ các nước trong khu vực. Đây cũng là cơ sở để Bloomberg cũng đưa ra nhận định Việt Nam tiềm năng để trở thành “con hổ” của châu Á vào năm ngoái.

Tuy nhiên, theo PGS.TS Bùi Tất Thắng, Viện Chiến lược Phát triển, Việt Nam đang đối mặt với nhiều thách thức, mà trước hết là tốc độ tăng trưởng kinh tế đang giảm dần qua mỗi 5 năm kể từ đầu những năm 1990; thách thức già hóa dân số với nguy cơ chưa giàu đã già cũng đang đặt ra. Thêm vào đó là những vấn đề đặt ra như thu chi ngân sách luôn căng thẳng, gánh nặng nợ công, rủi ro tiềm ẩn về môi trường...

"Nguy cơ tụt hậu là một trong những vấn đề nóng bỏng, trong đó có nguy cơ tụt hậu xa hơn về kinh tế. Sự cải thiện về chất lượng tăng trưởng và thể chế cũng không nhiều. Mặc dù Việt nam hoàn toàn có cơ sở để phát triển vượt bậc nhanh chóng và bền vững, thì Việt Nam cần có khát vọng với một cuộc cải cách mạnh mẽ, trên cơ sở xây dựng thể chế kinh tế thị trường, thúc đẩy sáng tạo, cạnh tranh và thúc đẩy sự phát triển của tầng lớp trung lưu" - PGS.TS. Bùi Tất Thắng khuyến nghị.

Theo Trí thức trẻ 


\section{Tài liệu tham khảo:}

[1] Phạm Minh Chính, Vương Quân Hoàng. (2009). Kinh tế Việt Nam: Thăng trầm và đột phá. NXB Chính trị quốc gia, Hà Nội.

[2] Cafef. (2015). Triển vọng kinh tế Việt Nam. https://cafef.vn/trien-vong-kinh-te-vietnam.html 